\title{
Synthesis of Ferrocenyl Alkenes, Dienes, and Enynes via Samarium Diiodide Promoted Tandem Addition and Dehydration of Ferrocenyl Carbonyls with Halides
}

\author{
Shean-J eng J ong and J im-Min Fang* \\ Department of Chemistry, National Taiwan University, Taiped, Taiwan 106, Republic of China \\ jmfang@mail.ch.ntu.edu.tw
}

Received February 4, 2001

\begin{abstract}
A practical method for preparation of ferrocenyl alkenes, dienes, and enynes from ferrocenyl carbonyls was explored. A one-pot operation using samarium diiodide to promote the condensation reactions of ferrocenecarboxaldehyde, acetylferrocene, benzoylferrocene, and butanoylferrocene with benzyl bromides, allyl bromide, propargyl bromide, and 1-bromo-3-chlorobutane gave the olefinic products in very high yields. The condensation reactions were also achieved by using catalytic amounts of $\mathrm{Sml}_{2}$ with magnesium to regenerate the divalent samarium reducing agent.
\end{abstract}

\section{Introduction}

Ferrocenyl alkenes and dienes are important substrates for applications in material science. ${ }^{1-3} \mathrm{~F}$ or example, 1-ferrocenyl-2-(4-nitrophenyl)ethane and the related ferrocenyl alkenes exhibit large optical nonlinearities useful for the development of optical information processing. ${ }^{1}$ F errocenyl 1,3-butadiene is an important substrate for manufacturing copolymers and homopolymers, ${ }^{2}$ which are employed as the coating material for aerospace transportation to enhance resistance against photodegradation. Ferrocene-1,3-butadiene can also be used as an enhancement fuel in solid propellants. ${ }^{2}$

(1) (a) Green, M. L. H.; Marder, S. R.; Thompson, M. E.; Bandy, J A.; Bloor, D.; Kolinsky, P. V.; J ones, R. J . Nature 1987, 330, 360. (b) Ghosal, S.; Samoc, M.; Prasad, P. N.; Tufariello, J . J J . Phys. Chem. 1990, 94, 2847. (c) Calabrese, J. C.; Cheng, L. T. J . Am. Chem. Soc. 1991, 113, 7227. (d) Bunting, H. E.; Green, M. L. H.; Marder, S. R.; Thompson, M. E.; Bloor, D.; Kolinsky, P. V.; J ones, R. J . Polyhedron 1992, 11, 1489. (e) Kott, K. L.: NcMahon, R. J J . Org. Chem. 1992. 57, 3097. (f) Wright, M. E.; Toplikar, E. G. Macromolecules 1992, 25 , 6050. (g) Togni, A.; Rihs, G. Organometallics 1993, 12, 3368. (h) Coe, B. J .; J ones, C. J .; McCleverty, J . A.; Bloor, D.; Cross, G.J . Organomet. Chem. 1994, 464, 225. (i) Alain, V.: Blanchard-Desce, M.: Chen, C.-T. Marder, S. R.; Fort, A.; Barzoukas, M. Synth. Met. 1996, 81, 133. (j) Mata, J .; Uriel, S.; Peris, E.; Llusar, R.; Houbrechts, S.; Persoons, A. J. Organomet. Chem. 1998, 562, 197. (k) Herrmann, R.; Pedersen, B. Wagner, G.; Youn, J.-H. J . Organomet. Chem. 1998, 571, 261. (I) Balavoine, G. G. A.; Daran, J .-C.; I ftime, G.; Lacroix, P. G.; Manoury E.; Delaire, J. A.; Maltey-Fanton, I.; Nakatani, K.; Bella, S. Di Organometallics 1999, 18, 21

(2) (a) Ponder, B. W.; Barnhill, C. W. US Patent 3739004, 1973. (b) Huskins, C. W.; Van Landuyt, D. C. US Patent 3843426, 1974. (c) Gauiter, J. C. C.: Raynal, S. F. US Patent 4661608, 1987. (d) Gautier J. C. C.; F ontanille. M. H.; Raynal, S. F. US Patent 4647628, 1987. (e) Miller, E.J .; Weigelt, C. A.; Serth, J . A.; Rusyid, R.; Brenner, J .; Luck L. A.; Godlewski, M. J . Organomet. Chem. 1992, 440, 91. (f) Grevels, F.-W.; Kuran, A.; Ozkar, S.; Zora, M.J . Organomet. Chem. 1999, 587, 122

(3) For incorporation of ferrocenyl alkenes in charge-transfer complexes, porphyrins, crown ethers, see: (a) Togin, A.; Hobi, M,; Rihs, G.; Rist, G.; Albinati, A, Organometallics 1994, 73, 1224. (b) Andrews, M. P.; Blackburn, C.; McAleer, J . F.; Pater, V. D. J. Chem. Soc. Chem. Commun. 1987, 1122. (c) Burrell, A. K.; Campbell, W.; Officer, D. L. Tetrahedron Lett. 1997, 38, 1249. For spectroscopic and binding studies of ferrocene alkenes and polyenes, see: (d) Bochmann, M.; Lu, J .; Cannon, R. D. J . Organomet. Chem. 1996, 518, 97. (e) Sol caniova, E.; Toma, S.; Liptaj, T. Collect. Czech. Chem. Commun. 1986, 51, 670. (f) Liu, J .; Castro, R.; Abboud, K. A.; Kaifer, A. E. J . Org. Chem. 2000, 65, 6973. For use as an analogue of anticancer drug Tamoxifen, see: (g) Top, S.; Tang, J.; Vessieres, A., Carrez, D.; Provot, C.; J aouen, G. Chem. Commun. 1996, 955
Three general methods have been utilized in the preparation of ferrocenyl alkenes and dienes: (i) using Wittig reactions, ${ }^{4}$ (ii) using organometallic addition reactions, ${ }^{5}$ and (iii) using Heck coupling reactions. ${ }^{6} \mathrm{~A}$ preparation of ferrocenyl Wittig reagent is to activate (dimethylamino)methylferrocene by $\mathrm{Mel}$ and subsequently react with $\mathrm{Ph}_{3} \mathrm{P}$ and BuLi. ${ }^{4}$ The resulting phophorus ylide can couple with aromatic aldehydes and conjugated aldehydes to give ferrocenyl alkenes and dienes. Alternatively, using ferrocenylcarboxaldehyde and the phosphorus ylides generated from organic halides can also afford ferrocenyl alkenes and dienes. ${ }^{4}$ The drawbacks of Wittig reactions are that it takes two steps to prepare phosphorus ylides and the byproduct of phosphine oxides often causes problem in separation from the ferrocenyl products. The Wittig reaction of acetylferrocene with phosphorus ylides is complicated by the aldol reaction as the side route. ${ }^{2 e}$

The addition reactions of ferrocenyl carbonyl compounds with organolithium, ${ }^{2 a}$ organomagnesium, ${ }^{\text {aa-c }}$ and organozinc ${ }^{5 \mathrm{~d}}$ reagents have been studied in method ii. For example, allyllithium and allylmagnesium bromide react with ferrocenecarboxaldehyde to afford an addition product, 1-ferrocenyl-3-buten-1-ol. To obtain 1-ferrocenyl-1,3butadiene, a subsequent dehydration is required, either by using large amounts of dehydrating agents (e.g., $\mathrm{CuSO}_{4}$ and acidic $\mathrm{Al}_{2} \mathrm{O}_{3}$ ) or by refluxing azeotropically with a strong acid. An allylzinc reagent has been pre pared by treating allyl bromide with ultrafine zinc powders supported on graphite. U sing such active allyl-

(4) In addition to refs $1 d, f, i, j, 2 e$, and 3a,e, see: (a) Osgerby, J . M.; Pauson, P. L. I Chem. Soc 1961, 4604 (b) Ponder, B. W.: Kneisel, R. C.; Lewis, D. H. Org. Prep. Proc. Int. 1971, 3, 171. (c) Lewis, D. H. Neal, M. C.; Ponder, B. W. Synth. Commun. 1972, 2, 93. For a similar reaction using arsonium salts, see: (d) Y ou, X.; Sun, H.; Peng, X.; Yue, C.; Li, C.; Wu, H. Inorg. Chim. Acta 1995, 234, 139.

(5) In addition to ref 2a, see: (a) Van Landuyt, D. C. US Patent 3751441, 1973. (b) Stephens, W. D.; Willis, T. C.; Combs, C. S. US Patent 3847871, 1974. (c) Duran, M.; Konstantinovic, S.; Pavlovic, V.; Predojevic, J .; Ratkovic, Z.; Rufinska, A.; Simova, S. J . Serb. Chem. Soc. 1995, 60, 737. Chem. Abst. 124, 56207. (d) Qiu, C.; Zhang, Y. Huaxue Shiji 1992, 14, 104.

(6) (a) Koenig, B.; Zieg, H.; Bubenitschek, P.; J ones, P. G. Chem. Ber. 1994, 127, 1811. (b) Qian, Y. Huagong Shikan 1998, 12, 11. (c) Naskar, D.; Das, S. K.; Giribabu, L.; Maiya, B. G.; Roy, S. Organome tallics 2000, 19, 1464 
Scheme 1. Sml 2 -Promoted One-Pot Formation of Ferrocenyl Alkenes, Dienes, and Enynes

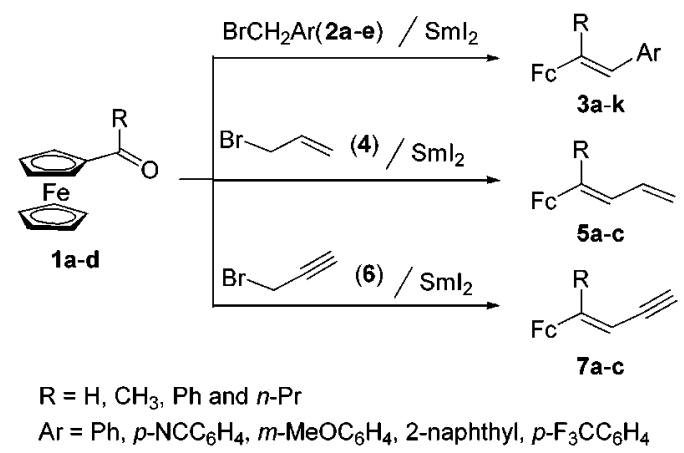

zinc reagent to react with ferrocenecarboxaldehyde gives directly 1 -ferrocenyl-1,3-butadiene in $85 \%$ yield. However, the yield decreases drastically if the zinc powder is not fine enough. As preparation of such active zinc powders involves mixing of melted potassium powders (highly active) with graphite and $\mathrm{ZnCl}_{2}$, one must take precautions during this hazardous operation.

Palladium-catalyzed Heck-type reactions for preparation of ferrocenyl al kenes have appeared in two reports. ${ }^{6}$ One paper shows the coupling reactions of vinylferrocene with aromatic and heteroaromatic halides by the catalysis of $\mathrm{Pd}(\mathrm{OAC})_{2}$, giving (1-ferrocenyl-2-aryl)ethenes. The drawback of this method is that vinylferrocene is not readily available and susceptible to polymerization. On the other hand, ferrocene is treated with $\mathrm{HgCl}_{2}$ to give ferrocenylmercury chloride, which undergoes coupling reactions with conjugated ol efins $\mathrm{H}_{2} \mathrm{C}=\mathrm{CHZ}$ ( $Z$ representing $\mathrm{CHO}, \mathrm{CO}_{2} \mathrm{Me}, \mathrm{CN}$, and 4-pyridyl) by the catalysis of $\mathrm{Li}_{2} \mathrm{PdCl}_{4}$. This method is limited to the synthesis of ferrocenyl al kenes $(\mathrm{FcCH}=\mathrm{CHZ})$ with electron-withdrawing groups. Synthesis of ferrocenyl 1,3-dienes by Hecktype coupling reactions has not yet been realized.

Kagan and co-workers have shown that $\mathrm{Sml}_{2}$ exhibits a high reducing power to convert alkyl bromides and iodides into the corresponding organosamarium halides with high efficiency. ${ }^{7}$ Barbier-type reactions of the resulting organosamarium reagents with carbonyl compounds afford the addition products of secondary and tertiary alcohols.

\section{Results and Discussion}

We demonstrate herein that condensation reactions of ferrocene carbonyls (1a-d) with benzyl bromides, allyl bromide, and propargyl bromide were achieved in a single step by the promotion of $\mathrm{Sml}_{2}$ (Scheme 1). A series of ferrocenyl alkenes $(\mathbf{3} \mathbf{a}-\mathbf{j})$, dienes $(\mathbf{5} \mathbf{a}-\mathbf{c})$, and enynes $(\mathbf{7 a}-\mathbf{c})$ were obtained in high yields (Table 1$)$.

The reaction was simply carried out by stirring a ferrocene carbonyl with an excess bromide in the presence of a stoichiometric amount of $\mathrm{Sml}_{2}$. The ferrocene carbonyls examined in this study included ferrocenecarboxaldehyde (1a), acetylferrocene (1) $)$, benzoylferrocene (1c) and butanoylferrocene (1d). The Sml 2 -promoted condensation reactions were clean, without pinacolic coupling ${ }^{8}$ of carbonyls or Wurtz coupling ${ }^{9}$ of bromides. The cyano, methoxy, and trifluoromethyl substituents on the phenyl rings of benzyl bromides $\mathbf{2} \mathbf{b}, \mathbf{2} \mathbf{c}$, and $\mathbf{2 e}$ were

(7) (a) Girard, P.; Namy, J .-L.; Kagan, H. B. J . Am. Chem. Soc. 1980, 102, 2693. (b) Hamann-Gaudinet, B.; Namy, J .-L.; Kagan, H. B. Tetrahedron Lett. 1997, 38, 6585.
Table 1. Reactions of Ferrocene Carbonyls (1a-d) with Benzyl Bromides (2a-d), Allyl Bromide, and Propargyl Bromide Using Stoichiometric Amounts of $\mathbf{S m l}_{2}$ (Scheme 1) $^{a}$

\begin{tabular}{|c|c|c|c|}
\hline entry & ferrocene & halide & $\begin{array}{c}\text { product } \\
\text { (yield, \%) }\end{array}$ \\
\hline 1 & $\mathbf{1 a}, \mathrm{R}=\mathrm{H}$ & $\mathbf{2 a}, \mathrm{Ar}=\mathrm{Ph}$ & $3 \mathbf{a}(95)^{c}$ \\
\hline 2 & $1 \mathbf{a}$ & $\mathbf{2 b}, \mathrm{Ar}=4-\mathrm{NCC}_{6} \mathrm{H}_{4}$ & $\mathbf{3 b}(95)^{c}$ \\
\hline 3 & la & $\mathbf{2 c}, \mathrm{Ar}=3-\mathrm{MeOC}_{6} \mathrm{H}_{4}$ & $3 c(90)^{c}$ \\
\hline 4 & la & 2d. $\mathrm{Ar}=2$-naphthyl & $3 d(75)^{c}$ \\
\hline 5 & $\mathbf{l b}, \mathrm{R}=\mathrm{CH}_{3}$ & $2 a$ & $3 e(98)^{c}$ \\
\hline 6 & lb & $2 b$ & 3f $(99)^{\mathrm{c}}$ \\
\hline 7 & $\mathbf{l b}$ & $\mathbf{2 e}, \mathrm{Ar}=4-\mathrm{F}_{3} \mathrm{CC}_{6} \mathrm{H}_{4}$ & $3 \mathbf{g}(98)^{c}$ \\
\hline 8 & $1 c \cdot R=P h$ & $2 a$ & 3 h $(98)^{c}$ \\
\hline 9 & 1c & $2 \mathbf{b}$ & $3 \mathbf{i}(99)^{\mathrm{c}}$ \\
\hline 10 & 1c & 2c & $3)^{(92)^{c}}$ \\
\hline 11 & 1c & 2d & $3 \mathbf{k}(88)^{\mathrm{c}}$ \\
\hline 12 & la & allyl bromide (4) & $5 \mathbf{a}(98)^{c}$ \\
\hline 13 & 1b & 4 & $\mathbf{5 b}(99)^{c}$ \\
\hline 14 & Ic & 4 & $5 c(99)^{c}$ \\
\hline 15 & lb & proparayl bromide (6) & $7 a(98)^{d}$ \\
\hline 16 & 1c & 6 & $\mathbf{7 b}(96)^{\mathrm{e}}$ \\
\hline 17 & 1d, $R=n-P r$ & 6 & 7c $(99)^{f}$ \\
\hline
\end{tabular}

a Under an atmosphere of argon, an appropriate halide (2.0 $\mathrm{mmol}$ in $5 \mathrm{~mL}$ of THF) and ferrocene carbonyl (1.2 mmol in $5 \mathrm{~mL}$ of THF) were added consecutively to a freshly prepared $\mathrm{Sml}_{2}$ solution ( $1.8 \mathrm{mmol}$ in $20 \mathrm{~mL}$ of THF) at $0{ }^{\circ} \mathrm{C}$. The mixture was stirred for $0.5-2 \mathrm{~h}$. The septum was removed, and the mixture was stirred at room temperature for an additional $15-24 \mathrm{~h}$ to give the desired products. $\mathrm{b}$ The yields are reported on the basis of the molar quantity of the ferrocenyl reagents. ' The product had (E)configuration. ${ }^{d}$ Enyne $7 a$ contained (E)- and (Z)-isomers in a ratio of 90:10. e Enyne $\mathbf{7 b}$ contained (E)- and (Z)-isomers in a ratio of 82:18. ${ }^{f}$ Enyne 7c contained (E)- and (Z)-isomers in a ratio of 95:5.

retained under such reaction conditions (entries 2, 3, and 7, Table 1). Compounds $\mathbf{3 a},{ }^{3 e} \mathbf{3 b},{ }^{1 c}$ and $\mathbf{5} \mathbf{a}^{4 a, b}$ are known compounds, whereas the structures of others products were determined by spectral methods. The products $\mathbf{3 a}-\mathbf{k}$ and $\mathbf{5 a}-\mathbf{c}$ consistently had (E)-configurations as characterized by the large coupl ing constants (ca. $16 \mathrm{~Hz}$ ) between olefinic protons in their ${ }^{1} \mathrm{H}$ NMR spectra. The stereochemistry of $\mathbf{3 g}$ and $\mathbf{3 i}$ was further confirmed by $\mathrm{X}$-ray diffraction analyses. Enynes $\mathbf{7 a}-\mathbf{c}$ existing as mixtures of (E)- and (Z)-isomers with preponderance of the (E)-isomers (82-95\%). An NOESY study of $\mathbf{7 b}$ isomers supported their structural assignments. Thus, the vinyl proton of (E)-7b occurring at $\delta 6.00$ showed an NOE correlation with the ferrocenyl protons, whereas that of (Z)-7b appearing at $\delta 5.58$ had an NOE correlation with the phenyl protons.

The Sml ${ }_{2}$-promoted reaction of ferrocenyl carbonyl with halides conceivably proceeded with a Barbier-type addition intermediate, as exemplified by al koxide $\mathbf{A}$ derived from the reaction with allylsamarium. I ndeed, the alkoxide intermediate $\mathbf{A}$ was hydrolyzed to give the corresponding al cohol $(\mathbf{8} \mathbf{a}-\mathbf{c})$ by quenching with water (Scheme 2). Elimination of $\mathrm{HOSml}_{2}$ would lead to the conjugated ferrocenyl dienes $\mathbf{5 a}-\mathbf{c}$. This process was presumably promoted by trivalent samarium ion (as a Lewis acid) generated in situ. Formation of a transient $\alpha$-carbonium ion could be facilitated by the adjacent ferrocenyl moi-

(8) F or $\mathrm{Sml}_{2}$-mediated pinacol coupling reactions of ferrocenyl carbonyls, see: (a) Taniguchi, N.; Uemura, M. Tetrahedron 1998, 54, 12775. (b) J ong, S.-J .; Fang, J .-M.; Lin, C.-H. J . Organomet. Chem. 1999, 590, 42. (c) Christensen, Torben B.; Riber, D.; Daasbjerg, K. Skrydstrup, T. Chem. Commun. 1999, 2051.

(9) In the absence of carbonyl compounds, treatment of benzyl bromide with $\mathrm{Sml}_{2}$ leads to a Wurtz coupling product, 1,2-diphenylethane. See refs 7 and $15 e$. 
Scheme 2. Reactions of Ferrocenyl Carbonyls with Allyl Bromide

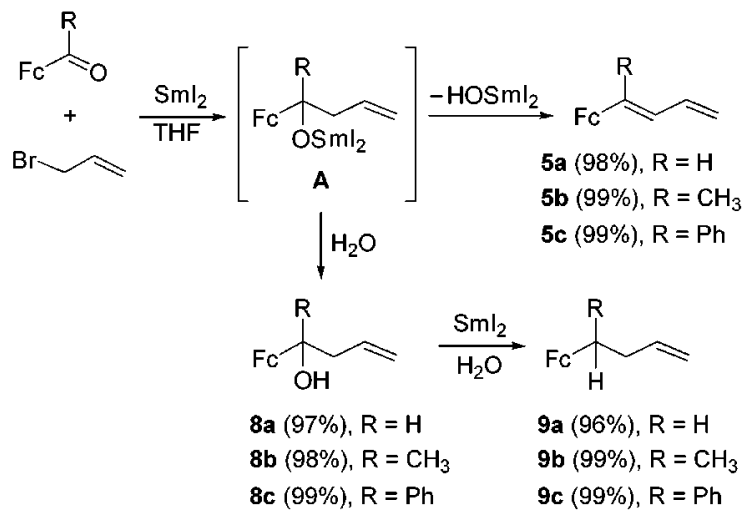

\section{Scheme 3. Reactions of Acetylferrocene with} Propargyl Bromide

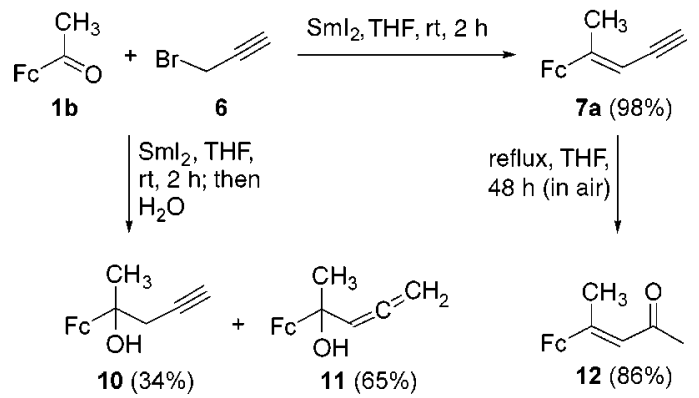

ety. ${ }^{10}$ We also carried out a deoxygenation of alcohols $\mathbf{8 a}-\mathbf{c}$, giving excellent yiel ds of $\mathbf{9 a}-\mathbf{c}$, by treatment with $\mathrm{Sml}_{2}$ in refluxing THF using $\mathrm{H}_{2} \mathrm{O}$ (5.5 equiv) as the proton source. ${ }^{8 b, 11}$

The Sml 2 -promoted reaction of acetylfer rocene and propargyl bromide yielded a mixture of alkynyl alcohol $\mathbf{1 0}(34 \%)$ and allenyl al cohol $\mathbf{1 1}(65 \%)$ on quenching with water (Scheme 3). ${ }^{12} \mathrm{~A}$ conjugated ketone $\mathbf{1 2}$ was obtained in $86 \%$ yield ${ }^{13}$ when the reaction mixture was further refluxed in THF without rigorous exclusion of moisture. The facile hydration of alkynyl and allenyl groups was attributable to the promotion of trival ent samarium ions. Indeed, enyne 7a was converted in part to enone $\mathbf{1 2}$ on a silica gel column. I solation of enyne 7a was realized by chromatography on neutral alumina or on the silica gel pretreated with $\mathrm{Et}_{3} \mathrm{~N}$.

As $\mathrm{Sml}_{2}$ in THF hardly reduces al kyl chloride without using other activations (e.g., using a polar cosolvent HMPA or light irradiation), ${ }^{14}$ we were able to synthesize

(10) The ferrocenyl group is known to stabilize the $\alpha$-carbocation. For formation of ferrocenyl $\alpha$-carbocations from the corresponding alcohols and dienes, see: (a) Siglmueller, F.; Herrmann, R.; U gi, I. Tetrahedron 1986, 42, 5931. (b) Ortaggi, G. Gazz. Chim. Ital. 1987, 117, 75. (c) Zou, C.; Wrighton, M. S. J. Am. Chem. Soc. 1990, 112 7578. (d) Klimova, E. I.; Klimova, T. B.; Martinez, M. G.; Meleshonkova, N. N.; Ruis, L. R. Mendeleev Commun. 1997, 233.

(11) (a) Nesmeyanov, A. N.; Perevalova, E, G. Izyest. Akad. Nauk S.S.S.R., Otdel. Khim. Nauk 1961, 1982. This paper reports a preparation of 4 -ferrocenyl-1-butene (compound $9 a$ ) in $<50 \%$ yield by subsequent treatments of ( $\mathrm{N}, \mathrm{N}$-dimethylamino)methylferrocene with iodomethane and allylmagnesium bromide. For compound 9c, see: (b) Mayr, H.: Rau, D. Chem. Ber. 1994, 127, 2493.

(12) The Sml 2 -promoted Barbier reaction of propargyl bromide and 2-octanone gives 4-methyl-1-decyn-4-ol (37\%) and 4-methyl-1,2-decadien-4-ol (35\%). See ref 7a.

(13) Condensation of ferrocene with 2,4-pentanedione in $\mathrm{H}_{2} \mathrm{SO}_{4}$ or $\mathrm{POCl}_{3} / \mathrm{HClO}_{4}$ gives compound $\mathbf{1 2}$ in less than $35 \%$ yield. See: Temerov S. A.; Sachivko, A. V.; Tverdokhleov, V. P.; Tselinskii, I V.; Frolova, G. M. Zh. Org. Khim. 1991, 27, 918. 2-ferrocenyl-6-chloro-2-hexene (14) in 97\% yield from 1-bromo-3-chloropropane by the $\mathrm{Sml}_{2}$-promoted condensation with acetylferrocene (eq 1). Such selective transformation would not be feasible by the previous methods using organolithium or Grignard reagents.

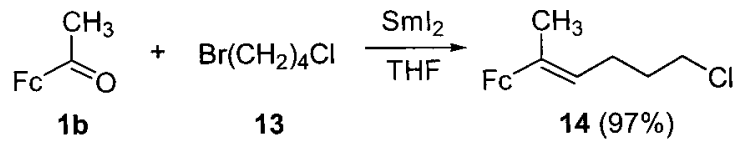

There are several reports on using catalytic amounts of $\mathrm{Sml}_{2}$ with an in situ regenerated system. ${ }^{15}$ Excess amounts of samarium, ${ }^{15 a}$ maganesi um, ${ }^{15 b, d}$ zinc amalgam ${ }^{15 c}$ and mischmetall (cerium mixed metal) ${ }^{15}$ have been employed with sub-stoichiometric amounts of $\mathrm{Sml}_{2}$ to effect a number of reactions, such as coupling of halides with ethynylsilanes, ${ }^{15 a}$ pinacolic coupling reactions of carbonyl compounds, $15 b$,e coupling of imines, ${ }^{15 d}$ coupling of acid chlorides, ${ }^{15 e}$ deoxygenation of oxiranes, ${ }^{15 c}$ reduction of iodoalkanes and benzyl bromides, ${ }^{15 e}$ cyclization of 1-iodo-6-phenyl-5-hexyne, radical $\pi$-cyclization of ketones with acrylate esters to form $\gamma$-lactones, ${ }^{15 c}$ and Barbier-type reactions. ${ }^{15 \mathrm{c}}$ In some cases, stoichiometric amounts of $\mathrm{Me}_{3} \mathrm{SiCl}^{15 b}$ or $\mathrm{Me}_{3} \mathrm{SiOTf}{ }^{15 c}$ are required for cleavage of $\mathrm{O}-\mathrm{Sm}(\mathrm{III})$ alkoxide bond to facilitate the reaction cycle.

A Sml 2 -promoted Barbier-type reactions of benzaldehydes with allyl bromide has been conducted by irradiation with high-pressure mercury lamp to regenerate $\mathrm{Sm}(\mathrm{II})$ species, ${ }^{16}$ presumably using the solvent THF as the reducing agent. The scope of this method is rather limited due to low yields and complication of side products. Aliphatic aldehydes and cinnamaldehyde also failed to react with allyl bromide under such photochemical conditions.

We also tested the feasibility of using magnesium metal to regenerate dival ent samarium reducing agent in the transformation of ferrocenyl carbonyl with halides (Table 2). In the absence of Sml 2 , treatment of acetylferrocene with the Grignard reagents of benzyl bromide and allyl bromide afforded only the addition products 15 and $\mathbf{8 b}$ (entries 1 and 8, Table 2). By using substoichiometric amounts of $\mathrm{Sml}_{2}$ (0.18-0.54 molar proportions) in the absence of $\mathbf{M g}$ metal, the yiel ds of $\mathbf{1 5}$ and $\mathbf{8 b}$ were low ( $\leq 15 \%)$ (entries 2 and 9, Table 2). Combined use of excess Mg (2-3 molar proportions) with substoichiometric amounts of $\mathrm{Sml}_{2}(0.18-0.54$ molar proportions) increased the yields of $\mathbf{1 5}(63 \%)$ and $\mathbf{8 b}(89-99 \%)$ to great extent (entries 3, 10, and 11). The reaction mixture in THF solution was thus refluxed for the indicated period to furnish the dehydration to give ferrocenyl alkene $3 \mathbf{e}$ and diene $\mathbf{5 b}$ in nearly quantitative yields (entries 4, 12 , and 13, Table 2).

4-Cyanobenzyl bromide did not react with acetylferrocene in the presence of $\mathrm{Mg}$ (entry 5, Table 2). However,

(14) (a) Inanaga, J .; I shikawa, M.; Yamaguchi, M. Chem. Lett. 1987 1485. (b) Ogawa, A.; Sumino, Y.; Nanke, T.; Ohya, S.; Sonoda, N.; Hirao, T. J . Am. Chem. Soc. 1997, 119, 2745. (c) Shabangi, M.; Flowers, R. A., II. Tetrahedron Lett. 1997, 38, 1137.

(15) (a) Murakami, M.; Hayashi, M.; Ito, Y. Synlett 1994, 757. (b) Nomura, R.; Matsuno, T.; Endo, T.J. Am. Chem. Soc. 1996, 118, 11666. (c) Corey, E. J .; Zhang, G. Z. Tetrahedron Lett. 1997, 38, 2045. (d) Annunziata, R.; Benaglia, M.; Cinquini, M.; Cozzi, F.; Raimondi, L. Tetrahedron Lett. 1998, 39, 3333. (e) Helion, F.; Namy, J.-L. J . Org Chem. 1999, 64, 2944

(16) Kondo, T.; Akazome, M.; Watanabe, Y. J . Chem. Soc., Chem Commun. 1991, 757. 
Table 2. Reactions of Acetylferrocene (1b) with Benzyl Bromides (2a,b), Allyl Bromide, and Propargyl Bromide Using Mg and Substoichiometric Amounts of $\mathrm{Sml}_{2}$ (Figure 1)a

\begin{tabular}{|c|c|c|c|c|}
\hline entry & halide & $\begin{array}{l}\text { halide/Mg/Sml } 2 \\
\text { molar proportions }\end{array}$ & $\begin{array}{l}\text { reaction conditions } \\
\left(\mathrm{T}\left({ }^{\circ} \mathrm{C}\right) \text {, time }(\mathrm{h})\right)\end{array}$ & $\begin{array}{l}\text { product } \\
\text { (yield, \%)c }\end{array}$ \\
\hline 1 & $\mathrm{PhCH}_{2} \mathrm{Br}$ & $1.5: 2: 0$ & $25,5^{d}$ & $15(28)$ \\
\hline 2 & $\mathrm{PhCH}_{2} \mathrm{Br}$ & $1.5: 0: 0.54$ & $25,3^{d}$ & 15 (15) \\
\hline 3 & $\mathrm{PhCH}_{2} \mathrm{Br}$ & $1.5: 2: 0.54$ & $25,3^{d}$ & 15 (63) \\
\hline 4 & $\mathrm{PhCH}_{2} \mathrm{Br}$ & $1.5: 2: 0.54$ & 25,$5 ; \mathrm{e} 68,48$ & $3 e(99)$ \\
\hline 5 & $4-\mathrm{NCC}_{6} \mathrm{H}_{4} \mathrm{CH}_{2} \mathrm{Br}$ & $1.5: 2: 0$ & 68,8 & no reaction \\
\hline 6 & 4-NCC ${ }_{6} \mathrm{H}_{4} \mathrm{CH}_{2} \mathrm{Br}$ & $1.5: 0: 0.54$ & 25,$15 ;, e 68,2$ & $3 f(16)$ \\
\hline 7 & $4-\mathrm{NCC}_{6} \mathrm{H}_{4} \mathrm{CH}_{2} \mathrm{Br}$ & $1.5: 2: 0.54$ & 25,$15 ;, \mathrm{e} 68,2$ & $3 f(52)$ \\
\hline 8 & $\mathrm{CH}_{2}=\mathrm{CHCH}_{2} \mathrm{Br}$ & $1.5: 2: 0$ & $25,10 \min ^{d}$ & $\mathbf{8 b}(60)$ \\
\hline 9 & $\mathrm{CH}_{2}=\mathrm{CHCH}_{2} \mathrm{Br}$ & $1.5: 0: 0.18$ & $25,10 \min ^{d}$ & $\mathbf{8 b}(11)$ \\
\hline 10 & $\mathrm{CH}_{2}=\mathrm{CHCH}_{2} \mathrm{Br}$ & $1.5: 2: 0.18$ & $25,10 \min ^{d}$ & $\mathbf{8 b}(89)$ \\
\hline 11 & $\mathrm{CH}_{2}=\mathrm{CHCH}_{2} \mathrm{Br}$ & $1.5: 3: 0.20$ & $25,1^{d}$ & $\mathbf{8 b}(99)$ \\
\hline 12 & $\mathrm{CH}_{2}=\mathrm{CHCH}_{2} \mathrm{Br}$ & $1.5: 3: 0.20$ & 25,$1 ; e 68,72$ & $\mathbf{5 b}(99)$ \\
\hline 13 & $\mathrm{CH}_{2}=\mathrm{CHCH}_{2} \mathrm{Br}$ & $1.5: 3: 0.54$ & 25,$1 ;{ }^{e} 68,2$ & 5b (99) \\
\hline 14 & propargyl bromide & $1.5: 3: 0.45$ & 25,$15 ; \mathrm{e} 68,12$ & 12 (59) \\
\hline
\end{tabular}

a The reaction was conducted by using $1 \mathrm{mmol}$ of acetylferrocene in THF solution. ${ }^{b}$ Based on the molar quantity of acetylferrocene. c The yields are reported based on the molar quantity of the ferrocenyl reagents. ${ }^{\mathrm{d}}$ After which, the reaction was quenched by addition of water. ${ }^{e}$ After which, the septum was removed, and the reaction mixture was refluxed for the indicated period.

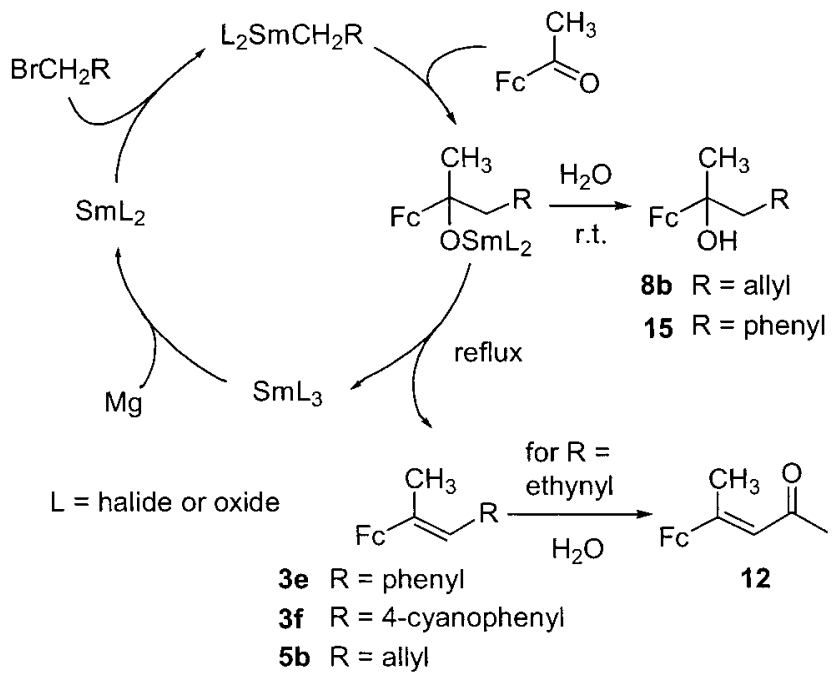

Figure 1. Proposed catalytic cycle for the reaction of acetylferrocene with halides in the presence of $\mathrm{Mg}$ and $\mathrm{Sml}_{2}$. The ligand $L$ represents halide or oxide.

a modest yield (52\%) of al kene $3 f$ was obtained by reflux in the presence of $\mathrm{Mg}$ and $\mathrm{Sml}_{2}$ (entry 7, Table 2). The reaction of acetylferrocene and propargyl bromide was similarly carried out by using Mg (3 molar proportions) and $\mathrm{Sml}_{2}$ (0.45 molar proportions) to give a $59 \%$ yield of enone 12 (entry 14, Table 2).

By analogy to the previously proposed reaction mechanisms, ${ }^{15 a, d}$ the above experimental results could be explained by a reaction cycle as depicted in Figure 1. Reduction of a bromide $\left(\mathrm{RCH}_{2} \mathrm{Br}\right.$ ) with $\mathrm{Sml}_{2}$ (or the related divalent samarium species) gave an organosamarium reagent ( $\mathrm{RCH}_{2} \mathrm{SmBrL}$, $\mathrm{L}$ is halide or oxide). The Barbier-type addition reaction with acetylferrocene led to an alkoxide intermediate, which could undergo either hydrolysis to give al cohols (e.g., $\mathbf{8 b}$ and $\mathbf{1 5}$ ) or elimination to give alkenes (e.g., $\mathbf{3 e}, \mathbf{3 f}$ and $\mathbf{5 b}$ ). The released trivalent samarium species ( $\mathrm{Sml}{ }_{2} \mathrm{OH}$ and analogues) could be reduced by $\mathrm{Mg}$ to regenerate divalent $\mathrm{SmL}$ for the next cycle of reactions.

In summary, we have developed a simple and expedient method for the preparation of ferrocenyl alkenes, dienes, and enynes from ferrocenyl carbonyls and halides by using $\mathrm{Sml}_{2}$ in one-pot operation. The $\mathrm{Sml}_{2}$-promoted reaction proceeded with a Barbier-type addition followed by elimination of $\mathrm{HOSml}_{2}$ to furnish the desired products in very high yields. The condensation reactions were also achieved by using catalytic amounts of $\mathrm{Sml}_{2}$ with excess magnesium to regenerate the dival ent samarium reducing agent. No silyl reagents such as $\mathrm{Me}_{3} \mathrm{SiCl}$ or $\mathrm{Me}_{3} \mathrm{SiOTf}$ were required in this regenerating system. Our present method is superior to previous methods in the sense of simple operation and high yields.

\section{Experimental Section}

Melting points are uncorrected. Chemical shifts are reported relative to $\mathrm{CHCl}_{3}\left(\delta_{\mathrm{H}} 7.26\right)$ and $\mathrm{CDCl}_{3}\left[\delta_{\mathrm{C}}\right.$ (central line of t) 77.0]. All reactions requiring anhydrous conditions were conducted in flame-dried apparatus under an atmosphere of nitrogen. Syringes and needles for the transfer of reagents were dried at $120^{\circ} \mathrm{C}$ and allowed to cool in a desiccator over $\mathrm{P}_{2} \mathrm{O}_{5}$ before use. Ethers were distilled from sodium benzophenone ketyl, and (chlorinated) hydrocarbons from $\mathrm{CaH}_{2}$. Column chromatography was generally carried out on Kieselgel 60 $(40-63 \mu \mathrm{m})$ unless specified. Merck silica gel 60F sheets were used for analytical thin-layer chromatography.

Representative Procedure for the Reactions of Ferrocene Carbonyls with Halides Using Stoichiometric Amounts of $\mathbf{S m l}_{2}$ (Table 1). Under an atmosphere of argon, a deep blue $S \mathrm{Sl}_{2}$ solution $(0.1 \mathrm{M})$ was prepared by treatment of Sm (331 mg, $2.2 \mathrm{mmol}$ ) with 1,2-di iodoethane (507 mg, 1.8 $\mathrm{mmol})$ in anhydrous THF (20 mL) for $1.5 \mathrm{~h}$ at room temperature. To the $\mathrm{Sml}_{2}$ solution (cooled in an ice bath) were added consecutively an appropriate halide (benzyl bromide $\mathbf{2 a}-\mathbf{d}$, allyl bromide, propargyl bromide, or 1-bromo-4-chlorobutane, $2.0 \mathrm{mmol}$ in $5 \mathrm{~mL}$ of THF) and ferrocene carbonyl (1a-d, 1.2 $\mathrm{mmol}$ in $5 \mathrm{~mL}$ of THF). The mixture was stirred for $0.5-2 \mathrm{~h}$. The septum was removed, and the mixture was stirred at room temperature for an additional 15-24 $\mathrm{h}$. The mixture was concentrated and chromatographed by elution with gradients of EtOAc/hexane (2:98 up to 1:1) to give the desired condensation products $(\mathbf{3} \mathbf{a}-\mathbf{j}, \mathbf{5} \mathbf{a}-\mathbf{c}, \mathbf{7} \mathbf{a}-\mathbf{c}$, and $\mathbf{1 4})$. The yields were reported based on the molar quantity of the ferrocenyl reagents. Silica gel was generally used for chromatography, but neutral alumina was preferable for isolation of enynes $7 a-c$.

Representative Procedure for the Reactions of Acetylferrocene with Halides Using Mg and Substoichiometric Amounts of $\mathbf{S m l}_{2}$ (Table 2). Under an atmosphere of argon, Mg powders (48 mg, $2 \mathrm{mmol}$ ) were placed in a round-bottomed flask. A freshly prepared $\mathrm{Sml}_{2}$ solution $(0.1 \mathrm{M})$ in anhydrous THF (2 mL) was added. A mixture of acetylferrocene $(229 \mathrm{mg}$, $1 \mathrm{mmol}$ ) and an appropriate halide (allyl bromide, benzyl bromide, 4-cyanobenzyl bromide, or propargyl bromide, 1.5 $\mathrm{mmol}$ in $20 \mathrm{~mL}$ of THF) was added. The deep blue col or of 
$\mathrm{Sml}_{2}$ discharged. After stirring for a certain period (10 min to $15 \mathrm{~h}$ ), the light blue color resumed. The septum was removed, and a reflux column was applied. The mixture was refluxed for 2-72 h, cooled, concentrated, and chromatographed by elution with gradients of EtOAc/hexane to give the desired condensation products.

4-Ferrocenyl-1,3-pentadiene (5b). According to the representative procedure, the $\mathrm{Sml}_{2}$-promoted condensation of acetylferrocene ( $274 \mathrm{mg}, 1.2 \mathrm{mmol}$ ) and allyl bromide (242 mg, $2.0 \mathrm{mmol}$ ) gave the title compound ( $302 \mathrm{mg}, 99 \%$ yield): orange solid, $55^{\circ} \mathrm{C}$; ${ }^{1} \mathrm{H} N M R\left(\mathrm{CDCl}_{3}, 300 \mathrm{MHz}\right) \delta 2.08\left(3 \mathrm{H}, \mathrm{s}, \mathrm{CH}_{3}\right)$, $4.10(5 \mathrm{H}, \mathrm{s}, \mathrm{Fc}), 4.23(2 \mathrm{H}, \mathrm{s}, \mathrm{Fc}), 4.40(2 \mathrm{H}, \mathrm{s}, \mathrm{Fc}), 5.07(1 \mathrm{H}$, d, J $=11.0 \mathrm{~Hz}), 5.19(1 \mathrm{H} . \mathrm{d} . \mathrm{J}=16.7 \mathrm{~Hz}), 6.29(1 \mathrm{H}, \mathrm{d}, \mathrm{J}=$ $11.0 \mathrm{~Hz}), 6.67(1 \mathrm{H}, \mathrm{m}) ;{ }^{13} \mathrm{C} \mathrm{NMR}\left(\mathrm{CDCl}_{3}, 75 \mathrm{MHz}\right) \delta 15.7,65.6$ $(2 \times), 68.8(2 \times), 69.1(5 \times), 115.0,123.6,133.5,135.3$; FAB-MS $\mathrm{m} / \mathrm{z} 252\left(\mathrm{M}^{+}\right)$. Anal. Calcd for $\mathrm{C}_{15} \mathrm{H}_{16} \mathrm{Fe}$ : C, 71.45; $\mathrm{H}, 6.40$. Found: C, 71.57; H, 6.71.

4-Ferrocenyl-3-hepten-1-yne (7c). According to the representative procedure, the $\mathrm{Sml}_{2}$-promoted condensation of butanoylfer rocene (307 mg, $1.2 \mathrm{mmol}$ ) and propargyl bromide (238 mg, $2.0 \mathrm{mmol}$ ) gave the title compound (333 mg, 99\% yield) as a mixture of (E)- and Z)-isomers (95:5) after chromatography on neutral $\mathrm{Al}_{2} \mathrm{O}_{3}$ : red-brown oil; IR $(\mathrm{KBr}) 2084$, $1641 \mathrm{~cm}^{-1}$; ${ }^{1} \mathrm{H} \mathrm{NMR}\left(\mathrm{CDCl}_{3}, 300 \mathrm{MHz}\right) \delta 1.02(3 \mathrm{H}, \mathrm{t}, \mathrm{J}=7.7$ $\mathrm{Hz}) / 0.99,1.68-1.58(2 \mathrm{H}, \mathrm{m}), 2.60(2 \mathrm{H}, \mathrm{t}, \mathrm{J}=7.7 \mathrm{~Hz}), 3.22(1$ $\mathrm{H}, \mathrm{d}, \mathrm{J}=2.4 \mathrm{~Hz}), 4.12(5 \mathrm{H}, \mathrm{s}), 4.29(2 \mathrm{H}, \mathrm{m}), 4.41(2 \mathrm{H}, \mathrm{m}) /$ 4.96, $5.70(1 \mathrm{H}, \mathrm{d}, \mathrm{J}=2.4 \mathrm{~Hz}) / 5.42 ;{ }^{13} \mathrm{C} \mathrm{NMR}\left(\mathrm{CDCl}_{3}, 75 \mathrm{MHz}\right)$ $\delta$ 14.4, 23.2, 34.7, $66.1(2 \times), 69.4(7 \times), 81.4,82.7,100.9,154.7$; FAB-MS m/z $278\left(\mathrm{M}^{+}\right)$; HRMS calcd for $\mathrm{C}_{17} \mathrm{H}_{18} \mathrm{Fe} 278.0758$, found 278.0754 .

2-Ferrocenyl-4-buten-2-ol (8b). The Sml 2 -promoted addition reaction of allyl bromide $(242 \mathrm{mg}, 2.0 \mathrm{mmol})$ to acetylferrocene (274 mg, $1.2 \mathrm{mmol}$ ), by a procedure similar to that for $\mathbf{8 a}$, gave the title compound ( $316 \mathrm{mg}, 98 \%$ yield): orange oil; ${ }^{1} \mathrm{H} \mathrm{NMR}\left(\mathrm{CDCl}_{3}, 300 \mathrm{MHz}\right) \delta 1.46(3 \mathrm{H}, \mathrm{s}), 2.16(1 \mathrm{H}, \mathrm{br} \mathrm{s}$, $\mathrm{OH}), 2.33(1 \mathrm{H}, \mathrm{dd}, \mathrm{J}=13.7,7.5 \mathrm{~Hz}), 2.46(1 \mathrm{H}, \mathrm{dd}, \mathrm{J}=13.7$, $7.1 \mathrm{~Hz}), 4.07-4.21(9 \mathrm{H}, \mathrm{m}), 5.01(2 \mathrm{H}, \mathrm{m}), 5.75(1 \mathrm{H}, \mathrm{m}) ;{ }^{13} \mathrm{C}$ $\mathrm{NMR}\left(\mathrm{CDCl}_{3}, 75 \mathrm{MHz}\right) \delta 28.0,48.3,65.3,66.6,67.5,67.7,68.2$ $(5 \times), 70.4,99.3,117.7,134.4$; FAB-MS m/z $270\left(\mathrm{M}^{+}\right)$; HRMS calcd for $\mathrm{C}_{15} \mathrm{H}_{18} \mathrm{FeO} 270.0707$, found 270.0693 .

4-Ferrocenyl-1-pentene (9b). Reduction of alcohol $\mathbf{8 b}$ (270 $\mathrm{mg}, 1.0 \mathrm{mmol}$ ), by a procedure similar to that for $9 \mathrm{a}$, gave the title compound (252 mg, 99\% yield): brown oil; ${ }^{1} \mathrm{H}$ NMR $\left(\mathrm{CDCl}_{3}, 300 \mathrm{MHz}\right) \delta 1.20(3 \mathrm{H}, \mathrm{d}, \mathrm{J}=6.8 \mathrm{~Hz}), 2.04-2.12(1 \mathrm{H}$, $\mathrm{m}), 2.31-2.39(1 \mathrm{H}, \mathrm{m}), 2.51-2.58(1 \mathrm{H}, \mathrm{m}), 4.05(4 \mathrm{H}, \mathrm{s}), 4.11$ $(5 \mathrm{H}, \mathrm{s}), 4.97-5.03(2 \mathrm{H}, \mathrm{m}), 5.71-5.85(1 \mathrm{H}, \mathrm{m}) ;{ }^{13} \mathrm{C} \mathrm{NMR}$ $\left(\mathrm{CDCl}_{3}, 75 \mathrm{MHz}\right) \delta 20.0,29.7,33.0,43.1,65.9,66.8,66.9,67.0$, $68.3(5 \times), 95.4,115.7,137.4$; IR (KBr) $1640 \mathrm{~cm}^{-1}$; FAB-MS m/z $254\left(\mathrm{M}^{+}\right)$; HRMS calcd for $\mathrm{C}_{15} \mathrm{H}_{18} \mathrm{Fe} 254.0758$, found 254.0755 . Anal. Calcd for $\mathrm{C}_{15} \mathrm{H}_{18} \mathrm{Fe}$ : C, 70.89; $\mathrm{H}, 7.14$. Found: $\mathrm{C}, 71.19$; $\mathrm{H}, 7.54$.
2-Ferrocenyl-4-propyn-2-ol (10) and 2-Ferrocenyl-3,4pentadien-2-ol (11). The Sml 2 -promoted addition reaction of propargyl bromide ( $238 \mathrm{mg}, 2.0 \mathrm{mmol}$ ) to acetylfer rocene (274 $\mathrm{mg}, 1.2 \mathrm{mmol}$ ), by a procedure similar to that for $\mathbf{8 a}$, gave a mixture of alkynyl al cohol $\mathbf{1 0}$ and allenyl alcohol $\mathbf{1 1}$ in a ratio of $66: 34$ (320 mg, 99\% total yield): red-brown oil; IR ( $\mathrm{KBr}$ ) 3450, 1958, $1660 \mathrm{~cm}^{-1}$; ${ }^{1} \mathrm{H} \mathrm{NMR}\left(\mathrm{CDCl}_{3}, 300 \mathrm{MHz}\right.$, for compound 10) $\delta 1.60\left(3 \mathrm{H}, \mathrm{s}, \mathrm{CH}_{3}\right) .2 .06(1 \mathrm{H}, \mathrm{t}, \mathrm{J}=2.7 \mathrm{~Hz})$, $2.36(2 \mathrm{H}, \mathrm{br} \mathrm{s}, \mathrm{OH}), 2.53(1 \mathrm{H}, \mathrm{dd}, \mathrm{J}=2.7,16.6 \mathrm{~Hz}), 2.64$ (1 $\mathrm{H}, \mathrm{dd}, \mathrm{J}=2.7,16.6 \mathrm{~Hz}), 4.38-4.08(18 \mathrm{H}, \mathrm{m}) ;{ }^{1} \mathrm{H} \mathrm{NMR}\left(\mathrm{CDCl}_{3}\right.$, $300 \mathrm{MHz}$, for part of compound 11) $\delta 1.56(3 \mathrm{H}, \mathrm{s}), 4.91(2 \mathrm{H}$, $\mathrm{d}, \mathrm{J}=6.6 \mathrm{~Hz}), 5.56(1 \mathrm{H}, \mathrm{t}, \mathrm{J}=6.6 \mathrm{~Hz}) ; \mathrm{FAB}-\mathrm{MS} \mathrm{m} / \mathrm{z} 268$ $\left(\mathrm{M}^{+}\right)$; HRMS calcd for $\mathrm{C}_{15} \mathrm{H}_{16} \mathrm{FeO} 268.0551$, found 268.0548 .

4-Ferrocenyl-3-penten-2-one (12). ${ }^{13}$ Under an atmosphere of argon, a solution of propargyl bromide (238 mg, 2.0 $\mathrm{mmol})$ in THF (10 mL) was added to a freshly prepared $\mathrm{Sml}_{2}$ solution $(0.1 \mathrm{M})$ in THF $(20 \mathrm{~mL})$ followed by the addition of a solution of acetylferrocene ( $274 \mathrm{mg}, 1.2 \mathrm{mmol})$ in THF $(10 \mathrm{~mL})$. The mixture was stirred for $30 \mathrm{~min}$ at room temperature. The septum was removed, and the mixture was stirred for $2 \mathrm{~h}$ at room temperature and refluxed for $12 \mathrm{~h}$ to give the title compound ( $276 \mathrm{mg}, 86 \%$ yiel d) after chromatography on a silica gel column eluted with EtOAc/hexane (1:1): red-brown solid; $\mathrm{mp} \mathrm{80-82}{ }^{\circ} \mathrm{C}$; IR ( $\left.\mathrm{KBr}\right) 1670,1593 \mathrm{~cm}^{-1}$; ${ }^{1} \mathrm{H}$ NMR $\left(\mathrm{CDCl}_{3}\right.$, $300 \mathrm{MHz}) \delta 2.18(3 \mathrm{H}, \mathrm{s}), 2.45(3 \mathrm{H}, \mathrm{s}), 4.12(5 \mathrm{H}, \mathrm{s}), 4.38(2 \mathrm{H}$, $\mathrm{m}), 4.51(2 \mathrm{H}, \mathrm{m}), 6.38(1 \mathrm{H}, \mathrm{s}) ;{ }^{13} \mathrm{C} \mathrm{NMR}\left(\mathrm{CDCl}_{3}, 75 \mathrm{MHz}\right) \delta$ 17.7, 32.0, $67.0(2 \times), 69.3(5 \times), 70.5(2 \times), 85.2,119.4,155.1$, 197.7; FAB-MS $\left(\mathrm{C}_{15} \mathrm{H}_{16} \mathrm{FeO}\right) \mathrm{m} / \mathrm{z} 268\left(\mathrm{M}^{+}\right)$.

2-Ferrocenyl-6-chloro-2-hexene (14). According to the representative procedure, the $\mathrm{Sml}_{2}$-promoted condensation of acetylferrocene (274 mg, $1.2 \mathrm{mmol}$ ) and 1-bromo-4-chlorobutane (656 mg, $3.0 \mathrm{mmol}$ ) gave the titl e compound (350 mg, 97\% yield): red-brown oil; IR $(\mathrm{KBr}) 1674 \mathrm{~cm}^{-1}$; ${ }^{1} \mathrm{H} \mathrm{NMR}\left(\mathrm{CDCl}_{3}\right.$, $200 \mathrm{MHz}) \delta 1.89(2 \mathrm{H}, \mathrm{m}), 1.98(3 \mathrm{H}, \mathrm{Me}), 2.26(2 \mathrm{H}, \mathrm{m}), 3.56$ $(2 \mathrm{H}, \mathrm{t}, \mathrm{J}=6.5 \mathrm{~Hz}), 4.13(5 \mathrm{H}, \mathrm{s}), 4.21(2 \mathrm{H}, \mathrm{m}), 4.33(2 \mathrm{H}, \mathrm{m})$, $5.58(1 \mathrm{H}, \mathrm{m}) ;{ }^{13} \mathrm{C} \mathrm{NMR}\left(\mathrm{CDCl}_{3}, 50 \mathrm{MHz}\right) \delta 15.4,25.4,32.3$, 44.5, $65.1(2 \times), 68.2(2 \times), 68.9(5 \times), 89.1,121.5,132.9$; FAB-MS m/z $302\left(\mathrm{M}^{+}\right)$; HRMS calcd for $\mathrm{C}_{16} \mathrm{H}_{19} \mathrm{ClF}$ e 302.0525, found 302.0523 .

Acknowledgment. We thank the National Science Council for financial support.

Supporting Information Available: Additional experimental procedures and spectra of new compounds. This material is available free of charge via the Internet at http://pubs.acs.org.

J O015557R 